\title{
乱流中の速度三成分と変動圧力の同時計測*
}

\author{
大西 一弘 ${ }^{* 1}$, 寺島 修 ${ }^{* 2}$, 酒井 康彦*3, 長田 孝二*2 , 伊藤 靖仁 ${ }^{* 2}$
}

\section{Simultaneous Measurement of Three Velocity Components and Static Pressure in Turbulent Flows}

\author{
Kazuhiro ONISHI ${ }^{* 1}$, Osamu TERASHIMA, Yasuhiko SAKAI, \\ Kouji NAGATA and Yasumasa ITO \\ ${ }^{* 1}$ Department of Mechanical Science and Engineering, Nagoya University, \\ Furo-cho, Chikusa-ku, Nagoya-shi, Aichi, 464-8603, Japan
}

\begin{abstract}
A new probe for the simultaneous measurement of three velocity components and static pressure in turbulent flows is developed and its measurement accuracy is checked. The probe consists of two X-type hot-wire probes and a static pressure probe that is placed at the center of hot-wires. The static pressure tube is manufactured by using a micro fabricated metal tube and drill to improve the spatial resolution. The external diameter of the static pressure tube is 0.3 $\mathrm{mm}$ and its internal diameter is $0.2 \mathrm{~mm}$ with 8 static holes on the wall of the tube. The measurement error in the pressure measurement caused by the cross-flow is compensated by the measured instantaneous three velocity components by two $\mathrm{X}$-type hot-wire probes. The measurement results show that the cross-streamwise profile of the mean velocity, RMS value of the fluctuating three velocity components, and RMS value of the fluctuating pressure in a plane jet agree with those obtained in the previous studies. Further, it is also found that the profile of the production term and diffusion term in the turbulent energy transport equation which is directly estimated by the measured data is more improved than our previous studies. This is due to the improvement of the spatial resolution of the combined probe and the measurement accuracy of the velocity-kinematic energy correlation by the measurement of all three velocity components.
\end{abstract}

Key Words : Simultaneous Measurement, Pressure Measurement, Plane Turbulent Jet, Pressure Diffusion

\section{1. 緒言}

乱流を記述する基礎方程式である Navier-Stokes 方程式には変動速度と変動圧力に関する項が含まれているため， 乱流中の変動速度と変動圧力を同時に計測することは乱流現象解明の観点から非常に有益である．このため, 近 年では乱流中で変動速度と変動圧力を同時に計測する試みが広く行われるようになってきた (1)(2)(3).

このような背景から，著者らの研究グループでは流体中の変動速度と変動圧力の同時計測の精度の向上を目的 に，X 型熱線プローブを構成する二本の熱線の間に変動圧力計測用の静圧管を配置したプローブを製作し，光の 計測精度の妥当性を確認した ${ }^{(4)(5)}$. しかし , このプローブは速度二成分と変動圧力の同時計測を可能とするプロー

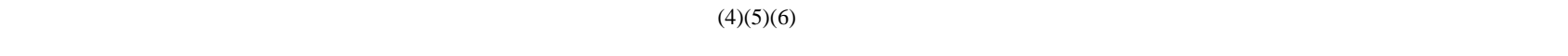

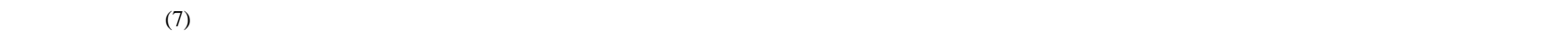
らず, 同時計測の精度に少なからず課題があった . また, 既報 ${ }^{(4)(5)(6)}$ で計測対象としていた二次元噴流に比べ, よ り三次元性の高い流れ場 (例えば, Geipel ら ${ }^{(8)}$ が研究の対象とした対向噴流など) における変動速度と変動圧力の 同時計測を実現するためには速度三成分と変動圧力の同時計測を行うことが望ましい．

产こで本研究では, 上述の課題の解決を図るため, 速度三成分と変動圧力を同時に計測するためのプローブを

\footnotetext{
* 原稿受付 2012 年 12 月 18 日

*1 学生員, 名古屋大学大学院工学研究科（干464-8603 愛知県名古屋市千種区不老町）

$*_{2}$ 正員, 名古屋大学大学院工学研究科

*3 正員, フェロー, 名古屋大学大学院工学研究科

E-mail: o-terashima@mech.nagoya-u.ac.jp
} 
製作した .プローブの製作に際しては, プローブの検査体積の低減 (計測時の空間分解能の向上) を目的に, 変動 圧力計測用の静圧管の小型化を試みた . また , 静圧管の小型化による乱流中の変動圧力の計測精度の低下要因の 抽出と光の補正・補償策を提案した . 光して, 二次元乱流噴流を対象に速度三成分と变動圧力の同時計測を行い， 製作した複合型プローブの計測精度を評価した .

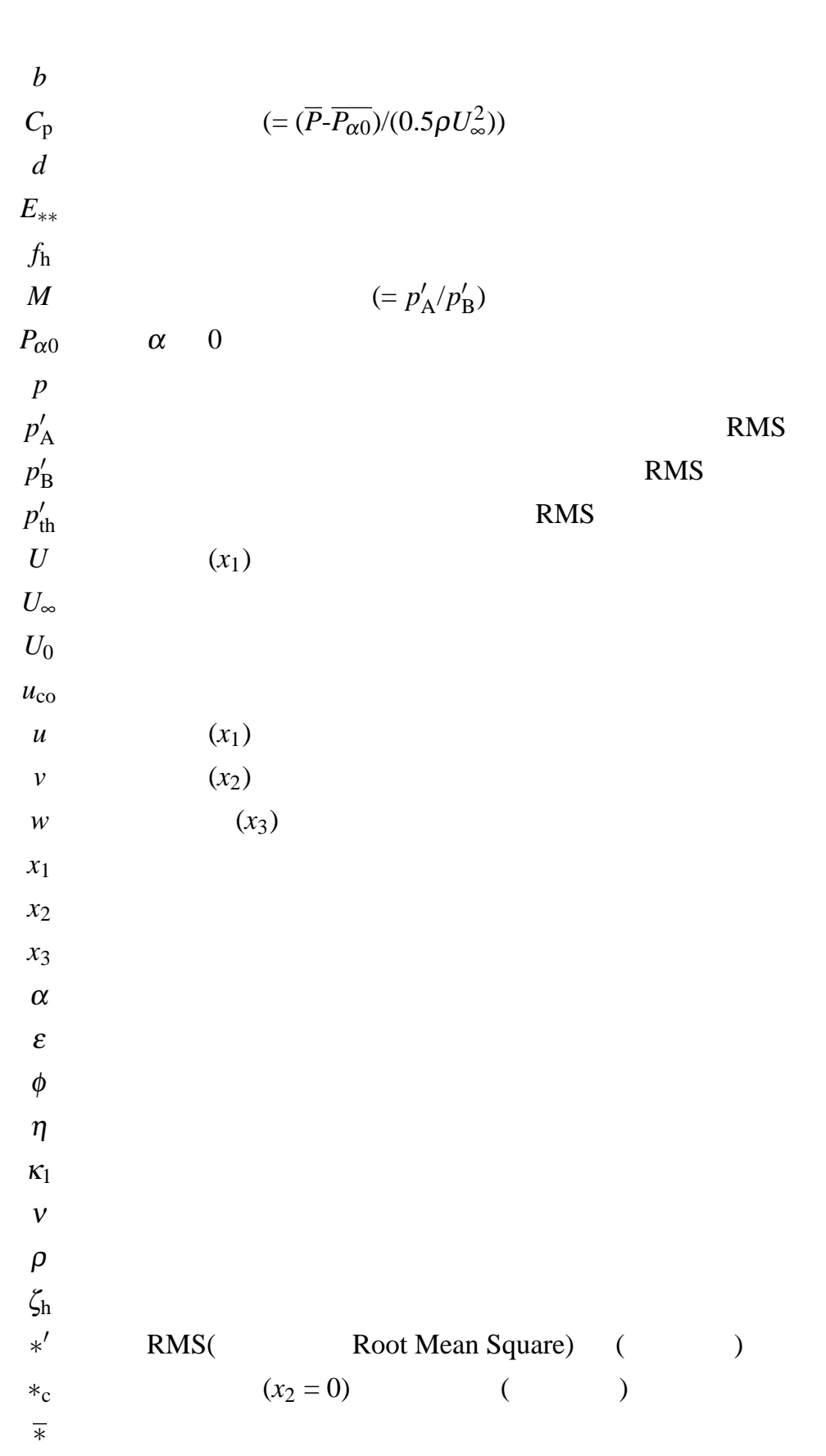

2. 速度三成分・変動圧力同時計測用プローブ

$2 \cdot 1$ プローブの構成と配置

図 1(a), (b) に速度三成分・変動圧力同時計測用プローブの寸法図, 写真を光れ光れ示す. 以降では速度三成分・ 変動圧力同時計測用プローブは複合型プローブ (Combined probe) と表記する . 複合型プローブは四本の熱線と一 本の静圧管で構成した . 四本の熱線で二組の X 型熱線プローブを構成し，四本の熱線の中央に変動圧力計測用の 静圧管を配置することで速度三成分と変動圧力の同時計測の実現を図った . 二つの熱線が交差する点と静圧管の 
(a)

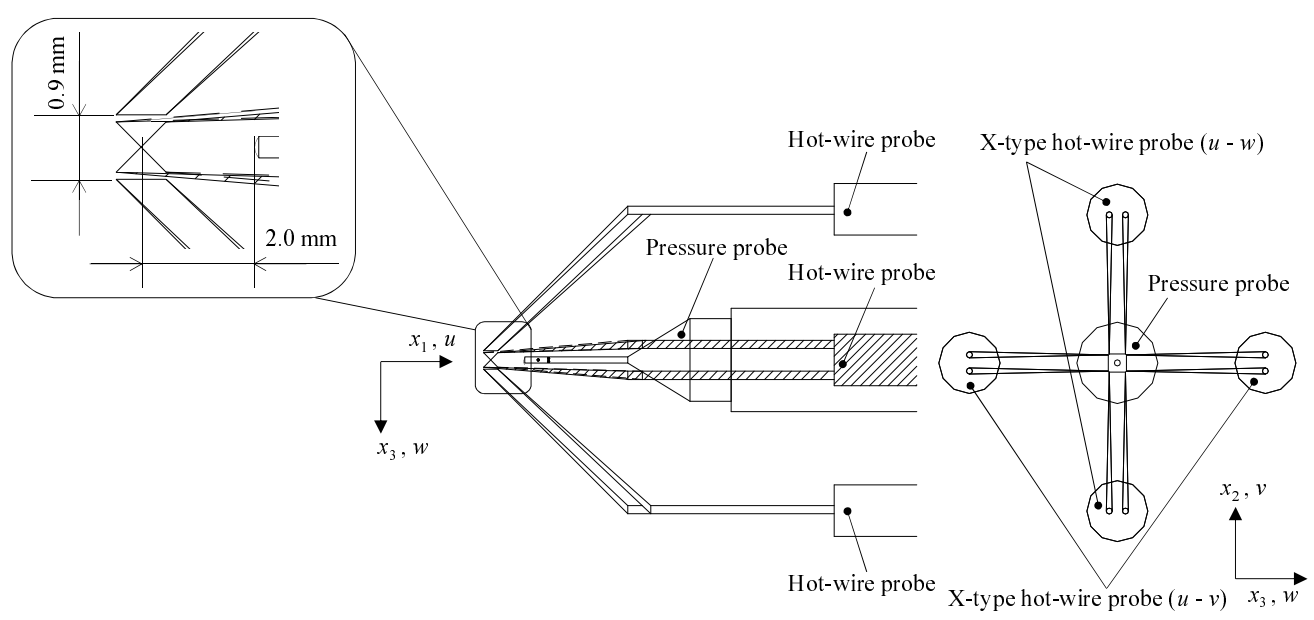

(b)

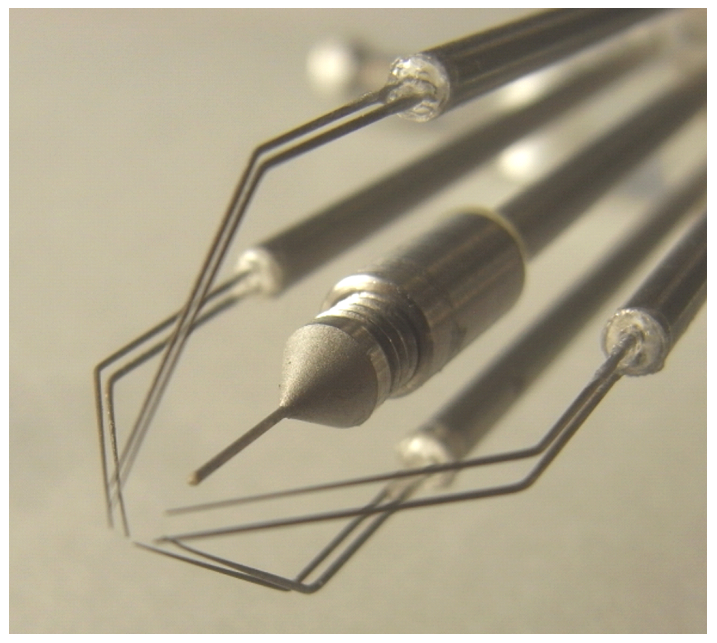

Fig. 1 (a) Dimensional drawing and (b) photograph of the combined probe

先端の主流方向距離 $(2.0 \mathrm{~mm})$ ，ならびに熱線のプロング間距離 $(0.9 \mathrm{~mm})$ は，これらの距離をパラメータとしてー 樣流中で行った予備実験にて複合型プローブによる計測結果か溔線プローブ, 圧カプローブ単独で計測した結果と 一致することを確認して決定した . 予備実験の方法の詳細は文献 ${ }^{(4)(5)}$ を参照されたい .

本研究では四本の熱線を静圧管の周囲に配置するため, 従来のプローブ(4)(5) $(\mathrm{X}$ 型熱線プローブの熱線間距離 : $1.5 \mathrm{~mm}$, 静圧管外径 : $0.5 \mathrm{~mm}$ ) に比べて同時計測時の検査体積が大きくなり，空間分解能が低下する．このため， 図 2 に示すように, 本研究では静圧管を既報 ${ }^{(4)(5)}$ に比べて小型化し, 外径を $0.3 \mathrm{~mm}$, 内径を $0.2 \mathrm{~mm}$, 静圧孔の直 径を $0.1 \mathrm{~mm}$ とした . 静圧管は MEMS 加工技術により製作した金属細管に微細ドリルで貫通孔をあけ，高圧流体 による洗浄により孔近傍を滑らかに仕上げて製作した .この小型化された静圧管を使用することにより，X型熱線 プローブの熱線間距離を $0.9 \mathrm{~mm}$ に縮めることが可能となった . また，静圧孔は静圧管の先端から $0.65 \mathrm{~mm}, 1.15$

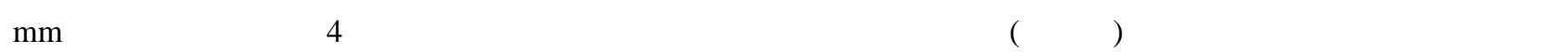
直径が 0.1 インチのマイクロホン (COUNTRYMAN 社製, B6W4, 感度 $16.0 \mathrm{mV} / \mathrm{Pa}$ ) を挿入した . なお，この静圧 管内を流れる空気の平均自由行程 $\lambda$ を $68 \mathrm{~nm}$, 代表長さ $L$ を静圧管の静圧孔の径 $(0.1 \mathrm{~mm})$ とすれば, クヌッセン 数 $\mathrm{Kn}(=\lambda / L)$ は 0.0007 となる .この值は静圧管内の空気を連続体とみなせる基準である $0.01^{(9)}$ より十分小さいこ とを記しておく . 


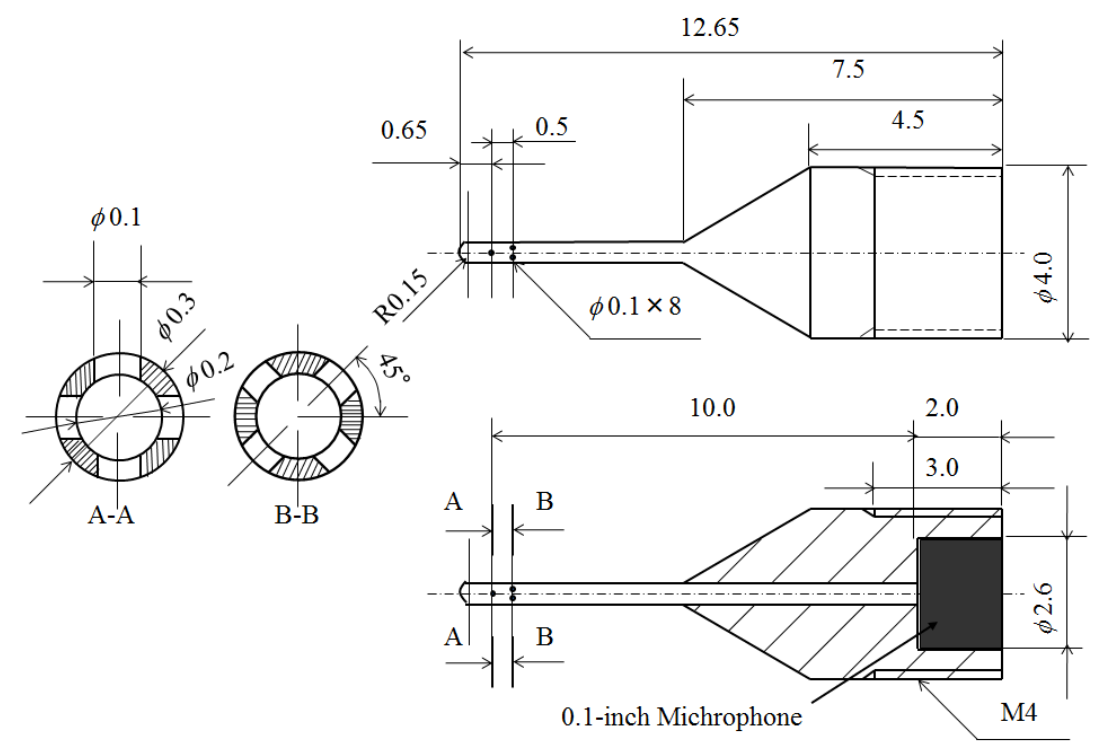

Fig. 2 Schematic view of the static pressure probe.

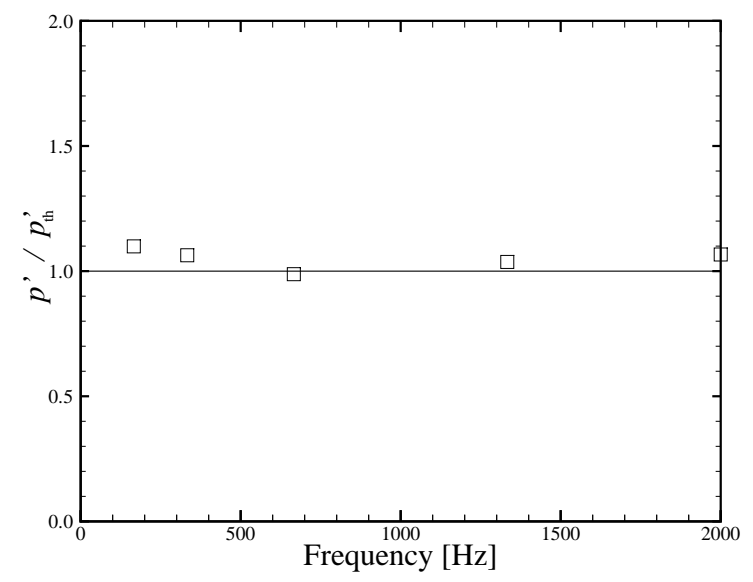

Fig. 3 Calibration result of the static pressure probe.

\section{$2 \cdot 2$ 変動圧力の計測精度に関する検討}

図 2 に示した静圧管を用いて変動圧力を計測する場合, 計測精度の観点から注意しなければならない点を四点 挙げる.一点目は変動速度による計測誤差, 二点目は静圧管に対する流れの角度と計測精度の誤差の関係, すなわ ち静圧管の角度特性 (Cross-flow error)，三点目はコンデンサマイクロホンの増幅部 (アンプ) で生じる時間遅れ (位 相差)による計測誤差，四点目は静圧管内に生じるヘルムホルツ共振やオルガンパイプ共振による計測誤差，すな わち静圧管の周波数応答特性と位相特性である .

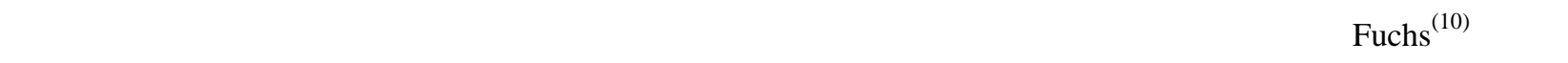
非粘性の運動量方程式から導かれた，ポテンシャル流における変動圧力 $p_{\mathrm{th}}^{\prime}$ と変動速度 $u^{\prime}$ の関係を表す式である。

$$
p_{\mathrm{th}}^{\prime}=-\rho\left(\overline{U_{\infty}}-u_{\mathrm{co}}\right) u^{\prime}
$$

ここで， $u_{\mathrm{co}}$ は周期的な変動速度の移流速度を表している，検定は，Toyoda ら ${ }^{(11)} に$ 倣い, 円柱後方に発生する力 ルマン渦列に伴って変動するポテンシャル流中で速度と圧力の計測を行い, 式 (1) を用いて変動速度から算出した 変動圧力の RMS 值と圧力プローブにより計測した変動圧力の RMS 值を比較する形で行った . 速度と圧力の計測 は円柱直径 $d=2-6 \mathrm{~mm}$, 主流速度 $U_{\infty}=5-20 \mathrm{~m} / \mathrm{s}$, 計測位置における速度変動の RMS 值 $u^{\prime}=0.12-0.54 \mathrm{~m} / \mathrm{s}$, 放出 周波数 160-2,000 Hz の条件の下で行った . なお，移流速度 $u_{\mathrm{co}}$ は Goldschmidt ら ${ }^{(12)}$ に倣い，計測位置の前後に I 型 熱線プローブを配置し，2 点の時空間相関が最大となる遅延時間と両者の間隔から算出した .

图 3 に検定結果を示す. 图 3 の横軸はカルマン渦列の渦放出周波数，縦軸は計測した変動圧力の RMS 值 $p^{\prime}$ と 


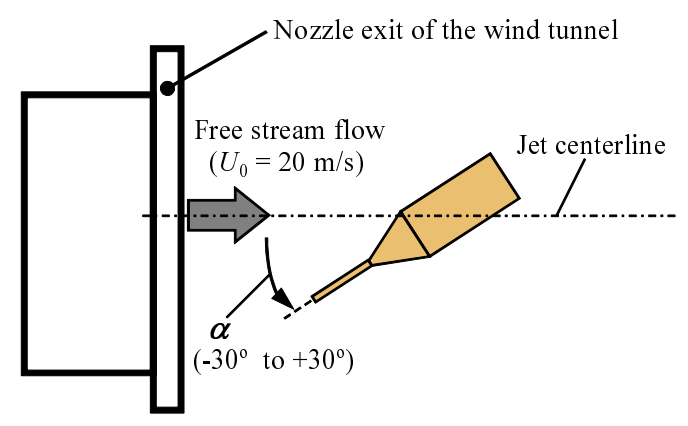

Fig. 4 Experimental apparatus for the cross-flow error check (Not to scale).

式 (1)より算出した変動圧力の RMS 值 $p_{\mathrm{th}}^{\prime}$ の比を表している . 图 3 より $, 2,000 \mathrm{~Hz}$ 以下の範囲で $p^{\prime} / p_{\mathrm{th}}^{\prime}$ が 1.1 以 下であることが確認できる．したがって，本研究で用いた圧力プローブの主流方向変動速度による計測誤差は 10 \%以下であるといえる .この結果は Toyoda ら ${ }^{(11)}$ が用いた圧力プローブの結果 (誤差 18 \%以下) と比べて小さい . これは, 本研究で用いた静圧管の外径や静圧孔の直径が Toyoda ら ${ }^{(1)}$ のプローブ (外径 $1.0 \mathrm{~mm}$, 静圧孔の直径 0.4 $\mathrm{mm})$ に比べ小さいためと考えられる . また , 類似の形状である Terashima ら ${ }^{(5)}$ が使用した圧力プローブの結果との 大きな差異は見られなかった .

二点目に挙げた静圧管の角度特性を評価するために行った検定試験と弚の結果について記す．検定試験は図 4 に 示すように, 吹出口の寸法が $80 \mathrm{~mm} \times 80 \mathrm{~mm}$ の吹出型の風洞のポテンシャルコア内に静圧管を設置し，風洞の主 流 $\left(U_{\infty}=20 \mathrm{~m} / \mathrm{s}\right.$ ) に対する静圧管の角度を変化させ, 静圧管に接続した微差圧計 (長野計器製 : GC15) で気流中の平 均静圧を計測する形で行った . 静圧管の角度は静圧管を電動ロータリーテーブル (SMC 社製 LER10J-R16N1, 繰 り返し位置決め精度 $\pm 0.05^{\circ}$ ) に取り付け，ロータリーテーブルの回転角度を基に調整した . 検定試験の方法の詳細 は文献 ${ }^{(13)(14)}$ を参照されたい .

図 5 に角度特性を評価した結果を示す. 図 5 の横軸は静圧管の主流に対する角度 $\alpha\left[^{\circ}{ }^{\circ}\right.$, 縦軸は静圧の時間平均 値 $\bar{P}$ を主流の動圧 $\left(=0.5 \rho U_{\infty}^{2}\right)$ と $\alpha$ が $0^{\circ}$ の時の静圧の時間平均值 $\overline{P_{\alpha 0}}$ で無次元化した圧力係数 $C_{\mathrm{p}}$ で,$C_{\mathrm{p}}$ の值が 0 に近いほど静圧の計測誤差が小さいことを表している. 図 5 中の記号は黑色の四角が本研究で使用した静圧管の 角度特性, 白抜きの三角が寺島ら ${ }^{(4)(5)}$ が使用した静圧管の角度特性である.なお，両者の $\overline{P_{\alpha 0}}$ の差異は主流の動圧 に対して 5.8\%であった . この差異は静圧管の外径や静圧孔の径の差異によるものと考えられる . 図 5 より, 本研 究で使用した静圧管は寺島らが使用した静圧管に比べて良好な角度特性を示しているが, $|\alpha|<10^{\circ}$ の範囲でも数 \%の計測誤差を有していることが分かる .

三点目に挙げたコンデンサマイクロホンの増幅部 (アンプ) で生じる時間遅れ (位相差)による計測誤差について 記す .コンデンサマイクロホンからの出力信号をプリアンプなどで増幅して計測する場合 , 出力信号に位相差が生 じること ${ }^{(1)}$, 圧力変動の符号と反対の符号の出力を示すことがある ${ }^{(10)}$. このため, 特に速度と圧力の相関を求 める際は, マイクロホンやアンプの位相 (出力) 特性を把握しておく必要がある. 乥こで本研究では, 使用するマ イクロホンの位相特性を調べるため, マイクロホンと半導体圧カセンサ (ENDEVCO 製, Model 8510B) をスピー カーの前に並べて配置し, 音波を発生させた際の両者から得られる波形を比較して位相特性を調べた．なお，こ こで使用した半導体圧力センサの位相遅れはほぼ 0 とみなすことができる．

図 6 に実験結果の一例として，600 Hz の音波を出した場合の両者の瞬時電圧波形の変動成分 $e$ を示す. 図中の

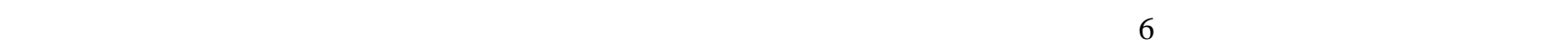
ロホンの出力が半導体圧力センサの出力に比べて 180 度ずれていることが確認できる . この位相特性は他の周波 数の変動圧力においても確認された .

四点目に挙げた静圧管内に生じるへルムホルツ共振やオルガンパイプ共振による計測誤差を評価するために行っ た検定試験の方法と結果について記す．検定試験は従来の方法 ${ }^{(6)(14)}$ と同樣に，スピーカーから $100 \sim 10,000 \mathrm{~Hz} の$ 音波を発生させた際の, 静圧管を取付けたマイクロホン (以下, マイクロホン A と表記) の出力信号と静圧管を取 付けていないマイクロホン (以下 , マイクロホン B と表記)の出力信号を比較する形で行った .

図 7(a) にマイクロホン A により計測した変動圧力の振幅 (RMS 值) $p_{\mathrm{A}}^{\prime}$ とマイクロホン B により計測した変動圧 


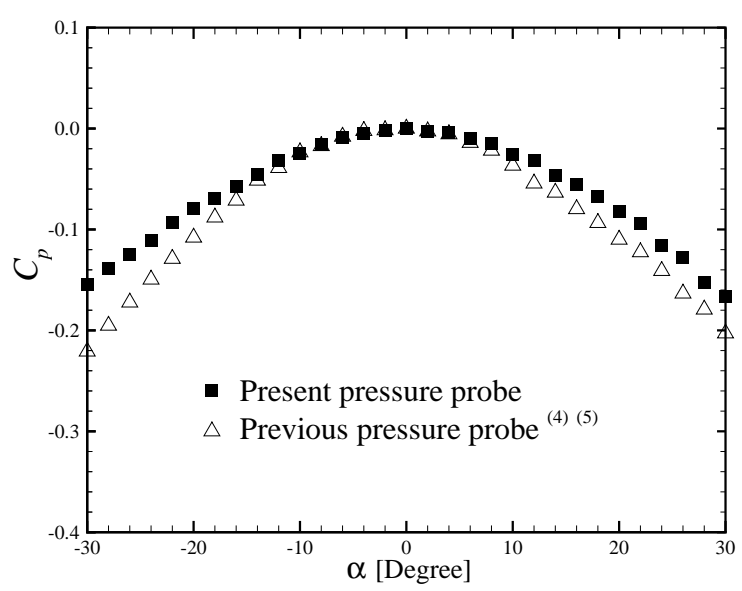

Fig. 5 Yaw angle characteristic of the static pressure probe.

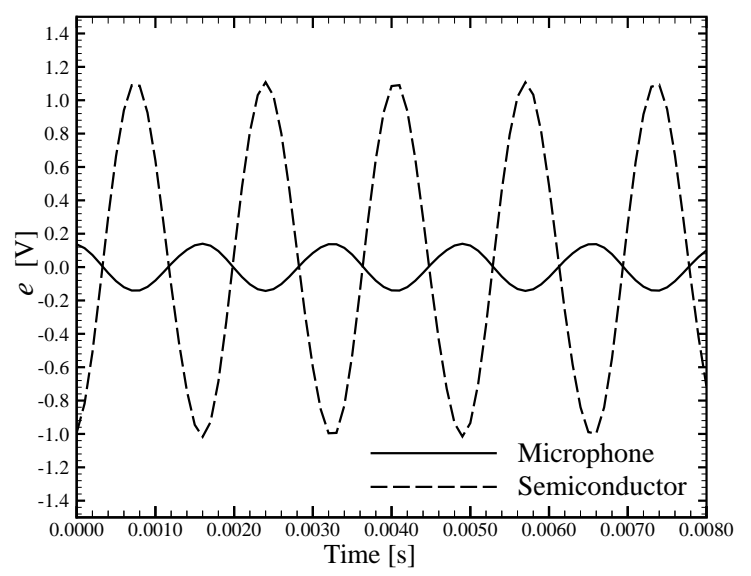

Fig. 6 Phase characteristic of the condenser microphone.

力の振幅 (RMS 值) $p_{\mathrm{B}}^{\prime}$ の比 $M$ を示す . 図 7(a) の横軸は音波の周波数 $f[\mathrm{~Hz}]$ ，縦軸は $M$ を表している . なお，振幅 比 $M$ はヘルムホルツ共振周波数 $f_{\mathrm{h}}$ と炎の減衰比 $\zeta_{\mathrm{h}}$ を用いて式 (2) で表すことができる .

$$
M=\frac{1}{\sqrt{\left\{1-\left(f / f_{\mathrm{h}}\right)^{2}\right\}^{2}+4 \zeta_{\mathrm{h}}^{2}\left(f / f_{\mathrm{h}}\right)^{2}}}
$$

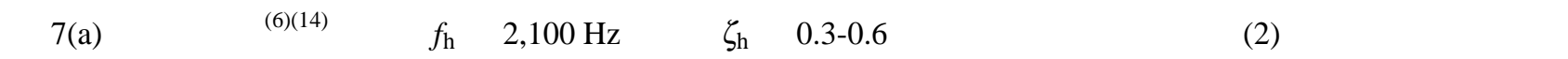
た . 図 7(a)より，M 2,000 Hz 以下ではほぼ 1 となっており, 静圧管がマイクロホンによる変動圧力の計測結果 に影響を及ぼしていないことが分かる.一方， $2,000 \mathrm{~Hz}$ を少し越えたところには $M$ が 1.3 程度となっているとこ ろがあり，理論式 ${ }^{(6)(14)}$ 通りにヘルムホルツ共振が発生し，Mの増加がもたらされていることが確認できる .

図 7(b) にマイクロホン $\mathrm{A}$ とマイクロホン B の出力信号の位相差 $\phi$ を示す . 図 7(b) の横軸は音波の周波数 $f[\mathrm{~Hz}]$, 縦軸は $\phi\left[^{\circ}\right]$ を表している . なお，位相差 $\phi$ は式 (3) で表すことができる .

$$
\phi=-\tan ^{-1} \frac{2 \zeta_{\mathrm{h}}\left(f / f_{\mathrm{h}}\right)}{1-\left(f / f_{\mathrm{h}}\right)^{2}}
$$

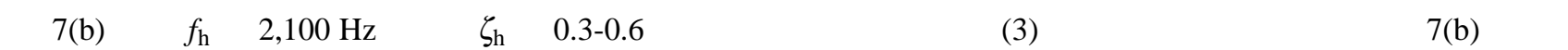
$500 \mathrm{~Hz}$ 以下では両者の位相差がほぼ 0 となっており，静圧管がマイクロホンによる圧力の計測結果に影響を及ぼ していないことが分かる.一方, $500 \mathrm{~Hz}$ 以上の周波数では位相遅れが生じていることが分かる .

以上の結果を踏まえ本研究では, 計測精度の向上と維持のため, 静圧管の角度特性 , マイクロホンの位相特性, 静圧管内に生じる共振特性，の三点に注意を払い計測を行った . 静圧管の角度特性により生じる計測誤差につい ては, 図 1 に示したX 型熱線プローブによる計測結果を基に補償した .すなわち, 速度三成分の計測結果から静 

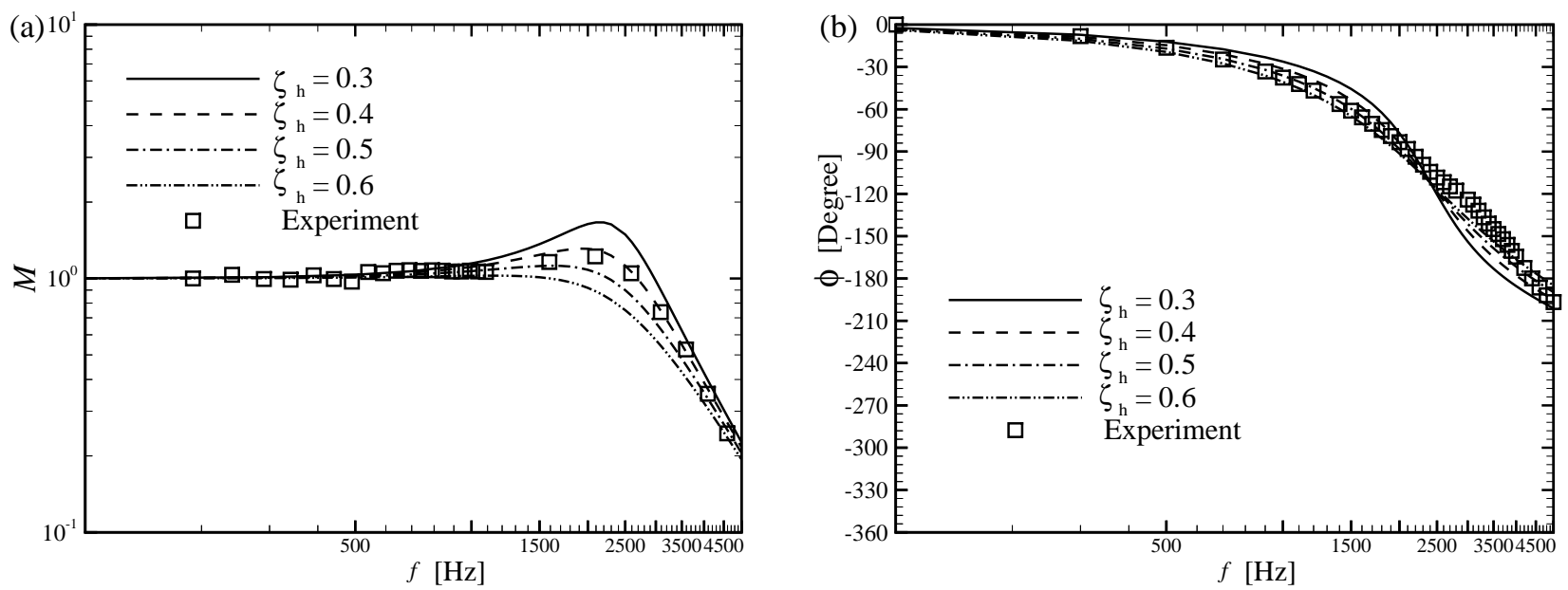

Fig. 7 (a) Amplitude ratio $M$ and (b) phase difference $\phi$ in the test of frequency response.

圧管に対する流れの角度を算出し, 兴の角度と図 5(a) に示した角度特性の評価結果から圧力の計測誤差の大きさ を求め，誤差分を近似的に補償した．この補償の妥当性については $3 \cdot 2 \cdot 1$ 節で示す．また，マイクロホンの位相特 性については出力信号の符号を反転させて補正し，500 Hz 以上の周波数の圧力の計測結果で生じる共振による振 幅や位相の誤差は, 従来の研究 ${ }^{(6)} に$ 倣いラプラス変換を用いて補正した .なお，これらの計測誤差のうち，角度特 性と共振特性は静圧管の小型化により生じたものである.計測精度の観点で見れば，補正を行わずに計測精度が 保証される計測手法が望ましいが, 本研究では小型化による計測時の空間分解能の向上を優先し, これらの補正 により計測精度の向上と維持を図った 。

\section{3. 複合型プローブによる二次元乱流噴流の計測}

本研究では, 複合型プローブの計測精度を検証するため, 二次元乱流噴流中で速度三成分と変動圧力の同時計 測を行った . また，複合型プローブで計測した結果を用いて二次元乱流噴流の乱れエネルギ収支を評価し，従来 の結果 ${ }^{(4)(5)(6)}$ と比較して考察した . 以下に実験方法と実験結果を記す。

\section{$3 \cdot 1$ 実験装置および実験条件}

図 8(a) に本研究で使用した二次元乱流噴流発生装置を示す. 本研究で使用した二次元乱流噴流発生装置は Sakai $ら^{(13)(15)(16)}$ による過去の報告で示したものと同一である．したがって，ここでは装置の簡単な説明のみ与える (詳 細は参考文献を参照されたい). 装置にはノズル出口から $1.0 \mathrm{~mm}$ 離れた場所にスキマー (Skimmer) を設置し，こ れによりノズル出口の流速が均一な部分のみを取り出した . 噴流の吹出口 (スキマー出口) の高さ $d$ は $12 \mathrm{~mm}$ で， 噴流出口のアスペクト比は 19.7 である . 座標系は噴流軸方向 (主流方向) を $x_{1}$, 垂直方向を $x_{2}$ ，スパン方向を $x_{3}$ とし, 噴流出口からの噴出レイノルズ数は $\operatorname{Re}=U_{0} d / v\left(U_{0}\right.$ : 噴流出口速度, $v:$ 動粘性係数 $)$ と定義し, 実験は $\operatorname{Re}$ =22,000で行った .

計測方法について記す．複合型プローブの熱線プローブは自作の定温度回路に接続した . この回路を使用した 場合の熱線の周波数応答特性を図 8(b) に示す. 図 8(b) の横軸は周波数, 縦軸は相対利得を表している . また , 周 波数応答特性は熱線を $20 \mathrm{~m} / \mathrm{s}$ の一樣流中に設置し, 西岡ら ${ }^{(17)}$ の手法に倣い定温度回路のブリッジの接点に微小な 正弦波電流を注入する形で調べた . 図 8(b) より, 熱線流速計の周波数応答特性は $5,000 \mathrm{~Hz}$ 程度までは利得がほぼ 1 となっていることが分かる. 図 7 , 図 8(b) の結果を踏まえ, 変動圧力計測用のマイクロホンからの出力と熱線

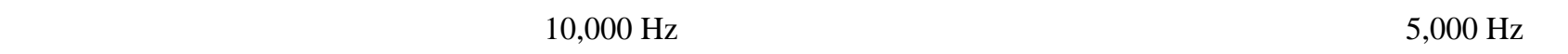
ローパスフィルタ処理を行った . 
(a)

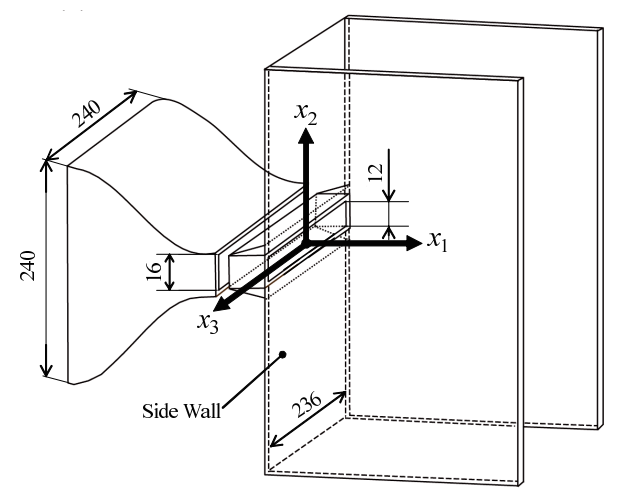

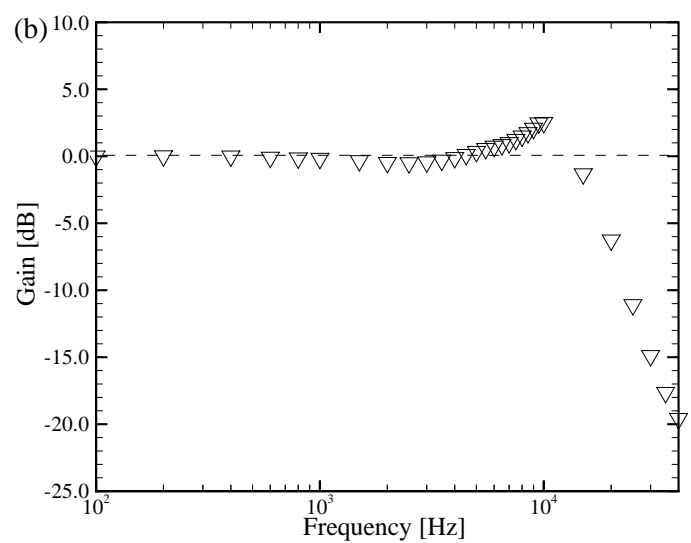

Fig. 8 (a) Schematic view of experimental apparatus (unit: $\mathrm{mm}$ ) and (b) results of frequency response test of constant temperature anemometer (CTA).

\section{$3 \cdot 2$ 実験結果}

\subsection{1 複合型プローブの計測精度}

図 9(a) に複合型プローブで計測した主流方向平均速度 $\bar{U}$ の噴流垂直方向分布を示す. 計測は $x_{1} / d=20$ で行っ た . 図 9(a) の横軸は噴流の垂直方向距離 $x_{2}$ を噴流の半值幅 $b$ で無次元化した值，縦軸は主流方向平均速度 $\bar{U}$ 噴流中心の值 $\overline{U_{\mathrm{c}}}$ で無次元化した值である . また , 図中の実線は I 型熱線プローブ単独で計測した結果 (実線で表 記)である . 図 9(a)より，複合型プローブによる計測結果はI 型熱線プローブ単独による計測結果と一致しており， 複合型プローブにより主流方向平均速度が正しく計測できていることが分かる.なお，両者の計測結果の $\overline{U_{\mathrm{c}}}$ の差

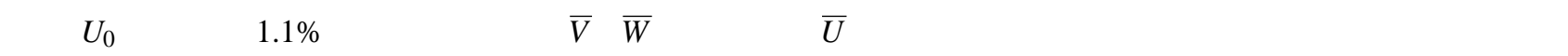
X 型熱線プローブによる計測結果が一致していることを記しておく .

図 9(b), (c) に複合型プローブで計測した变動速度と变動圧力の RMS 值の噴流垂直方向分布を示す. 計測は $x_{1} / d$ $=20$ で行った . 図 9(b) は主流方向変動速度の RMS 值 $u^{\prime}$, 垂直方向変動速度の RMS 值 $v^{\prime}$, およびスパン方向変動 速度の RMS 值 $w^{\prime}$, 図 9(c) は変動圧力の RMS 值 $p^{\prime}$ の噴流垂直方向分布である . 図 9(b) , (c) の横軸は噴流の垂直 方向距離 $x_{2}$ を噴流の半值幅 $b$ で無次元化した值，縦軸はRMS 值を光れ光れの噴流中心の值で無次元化した值で ある.また，図 9(b) 中の実線，破線，一点鎖線はX 型熱線プローブ(熱線間距離; $0.7 \mathrm{~mm}$, 以下同一), 図 9(c) 中 の実線は圧力プローブ単独で計測した結果を表している . 図 9(b)より，複合型プローブで計測した結果はX 型熱 線プローブで計測した結果と良く一致しており, 複合型プローブにより変動速度の RMS 值が正しく計測できてい ることが分かる．なお，複合型プローブで計測した結果と X 型熱線プローブ単独で計測した結果の $u_{\mathrm{c}}^{\prime}, v_{\mathrm{c}}^{\prime}, w_{\mathrm{c}}^{\prime}$ の差

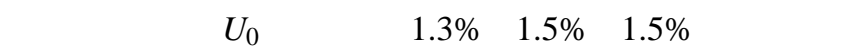

同樣に図 9(c) より，複合型プローブて計測した結果は圧力プローブ単独で計測した結果とよく一致しており，両

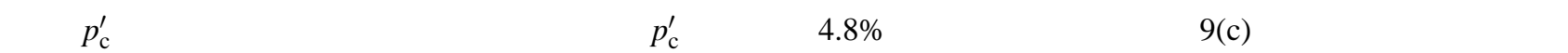
RMS 值 $p^{\prime}$ の噴流垂直方向分布は図中に破線で示したSakai ら ${ }^{(13)}$ による角度特性の優れた静圧管を用いた計測結果 に比へ， $x_{2} / b= \pm 1$ 付近でのピーク值が異なっている.これは $2 \cdot 2$ 節で示したように, 本研究で使用した静圧管の 角度特性によるもので, 変動速度が大きい, すなわち乱れの強い位置で炎の影響か顕著に表れ, 計測誤差が大き くなったものと考えられる. 乥こで, 速度三成分の計測結果から瞬時の速度べクトル $\tilde{U}, \tilde{V}, \tilde{W}$ を算出し, 光の結 果を基に流れの角度 $\tilde{\gamma}_{1}, \tilde{\gamma}_{2}$ (図 10 参照) を求め, 図 5(a) に示した角度特性の評価結果から圧力計測結果の誤差量を 見積り，予想される誤差分を近似的に補償した .なお，この計測位置 $\left(x_{1} / d=20\right)$ における $\tilde{\gamma}_{1}, \tilde{\gamma}_{2}$ の RMS 值は最 大で $6.0^{\circ}$ であった . 近似的に補償した值を用いて算出した変動圧力の RMS 值の噴流垂直方向分布を図 9(d) に示 す. 図 9(d)より，補償された結果は Sakai ら ${ }^{(13)}$ の結果とよく一致おり，補償後の $p_{\mathrm{c}}^{\prime}$ と Sakai ら ${ }^{(13)}$ の $p_{\mathrm{c}}^{\prime}$ の差異は 1.3\%であった .これより, 静圧管の角度特性による計測誤差の補償により，少なくとも過去の研究で使用された 角度特性の優れた圧カプローブと同等の精度の変動圧力計測が行えることが確認された .

図 11(a)-(d) に複合型プローブで計測した主流方向変動速度 $u$, 垂直方向変動速度 $v$, スパン方向変動速度 $w$, 変 

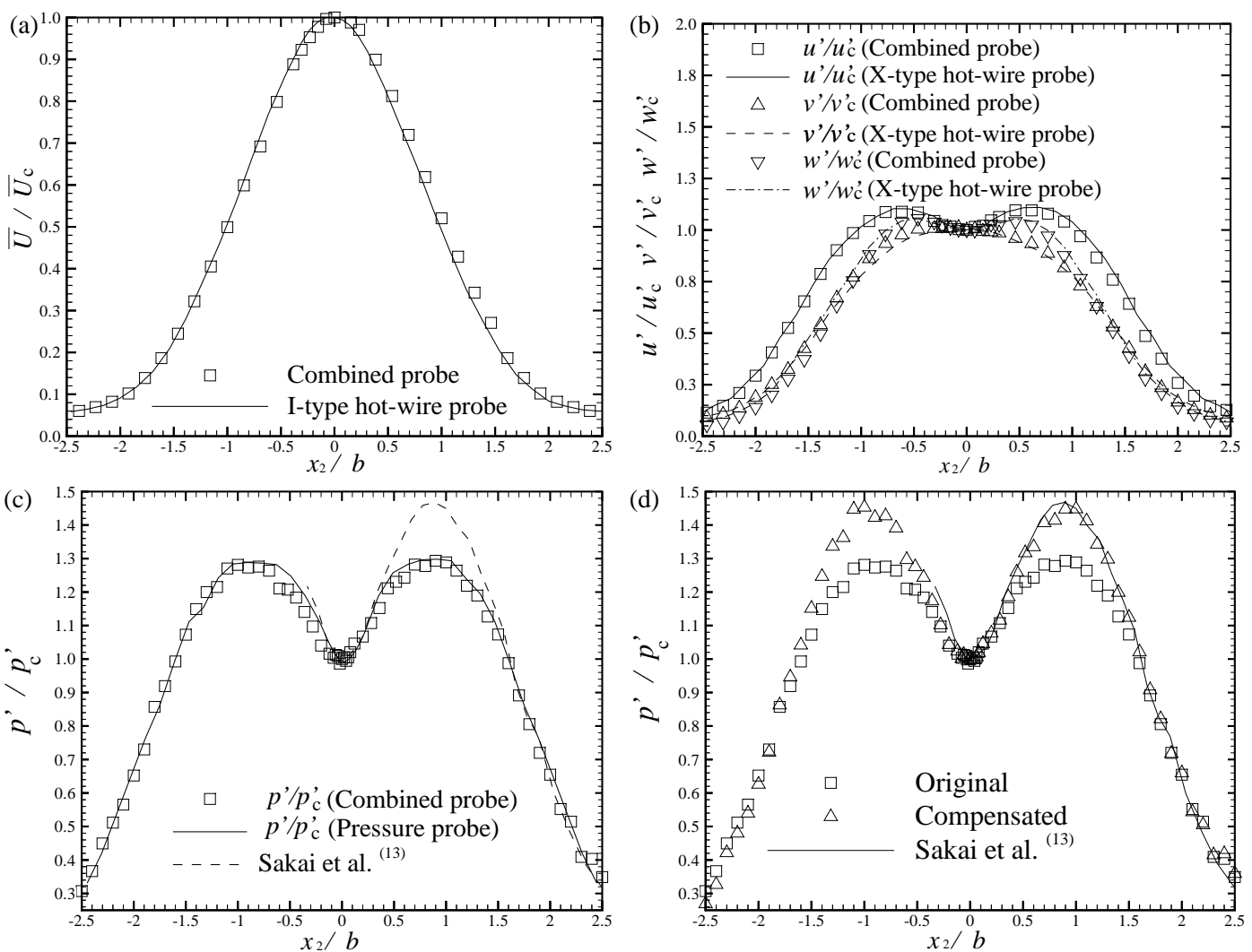

Fig. 9 Cross-streamwise profiles of (a) mean streamwise velocity $\bar{U} / \bar{U}_{\mathrm{c}}$, (b) RMS value of the streamwise velocity fluctuation $u^{\prime} / u_{\mathrm{c}}^{\prime}$ and cross-streamwise velocity fluctuation $v^{\prime} / v_{\mathrm{c}}^{\prime}$ and spanwise velocity fluctuation $w^{\prime} / w_{\mathrm{c}}^{\prime}$, (c) pressure fluctuation $p^{\prime} / p_{\mathrm{c}}^{\prime}$, and (d) compensated value of pressure fluctuation. The measurements are performed at $x_{1} / d=20$.

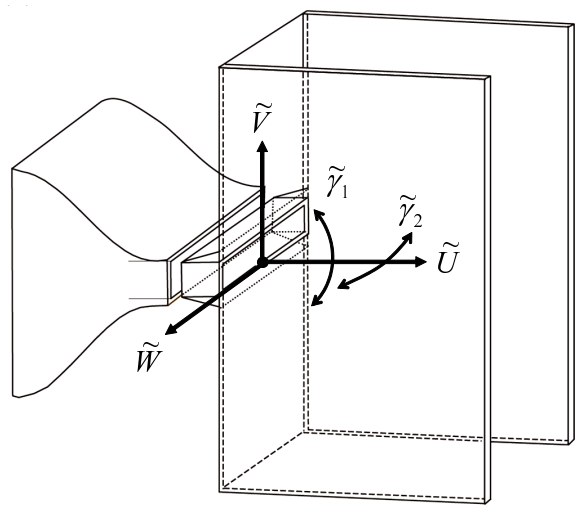

Fig. 10 Definitions of pitch angle $\tilde{\gamma}_{1}$ and yaw angle $\tilde{\gamma}_{2}$.

動圧力 $p$ のパワースペクトルを示す. 計測位置は $x_{1} / d=20, x_{2} / b=1.0$ である . 図 11(a)-(d) の横軸は噴流軸方向 の波数 $\kappa_{1}$ をコルモゴロフのマイクロスケール $\eta$ にって無次元化した值，図 11(a), (b), (c) の縦軸は単位質量あ たりのエネルギ散逸率 $\varepsilon$ と動粘性係数 $v$ で無次元化した值，図 11(d) の縦軸は空気の密度 $\rho$ と単位質量あたりの

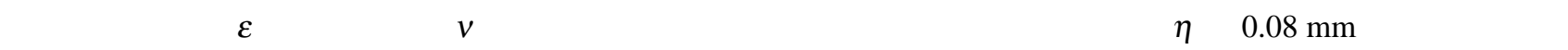
図 11(a)-(c)にはX 型熱線プローブ単独で計測した結果から算出したパワースペクトルを合わせて示した．なお， $\varepsilon$ 
と $\eta$ は以下の式により算出した .

$$
\begin{gathered}
\varepsilon=2 v \int_{0}^{\infty} \kappa^{2} E(\kappa) d k \\
\eta=\left(\frac{v^{3}}{\varepsilon}\right)^{\frac{1}{4}}
\end{gathered}
$$

ここで, $E(\kappa)$ は変動速度の三次元パワースペクトルで, 一次元のパワースペクトル $E_{1}\left(\kappa_{1}\right)$ と以下の関係となる. $E_{1}\left(\kappa_{1}\right)$ はオイラーの周波数スペクトル $E_{1}(f)$ からテイラーの凍結仮説を用いて求めた .

$$
E(\kappa)=\frac{1}{2}\left[\kappa_{1}^{3} \frac{d}{d \kappa_{1}}\left\{\frac{1}{\kappa_{1}} \frac{d}{d \kappa_{1}} E_{1}\left(\kappa_{1}\right)\right\}\right]_{\kappa_{1}=\kappa}
$$

また , 変動圧力のパワースペクトル $E_{p p}$ と変動圧力の RMS 值 $p^{\prime}$ の間には以下の関係がある.

$$
p^{\prime}=\sqrt{\overline{(\tilde{p}-\bar{p})^{2}}}=\int_{0}^{+\infty} E_{p p}\left(\kappa_{1}\right) d \kappa_{1}
$$

ここで, $p^{\prime}$ は変動圧力の RMS 值,$p$ は変動圧力の瞬時値, $\bar{p}$ は変動圧力の時間平均值である .

图 11(a)-(c)より，いずれのパワースペクトルについても複合型プローブで計測した結果から算出したパワース ペクトルとX 型熱線プローブ単独で計測した結果から算出したパワースペクトルは一致しており，複合型プローブ による計測結果が熱線の中央に配置した圧カプローブにより影響を受けていないことが分かる . 同樣に , 図 11(d) の変動圧力のパワースペクトル $E_{p p}$ より, 複合型プローブで計測した結果から算出したパワースペクトルと圧力 プローブ単独で計測した結果から算出したパワースペクトルは一致しており，複合型プローブによる計測結果が 圧カプローブの周囲に配置した熱線により影響を受けていないことが分かる．また，補償前，補償後，いずれの パワースペクトルにも-7/3 乗則に従う領域 ${ }^{(18)(19)}$ が確認でき, 図 9(d) に示した変動圧力の RMS 值の計測結果と同 樣に，補償された結果は Sakai ら ${ }^{(13)}$ の結果に近いものとなった .これより，静圧管の角度特性による計測誤差の 補償により, 過去の研究で使用された角度特性の優れた圧カプローブと同等の精度の変動圧力計測が行えること が改めて確認された .

以上の結果より, 本研究で製作した複合型プローブは計測時の空間分解能の向上が図られた上, 計測対象とし た $5,000 \mathrm{~Hz}$ 以下の変動周波数範囲において, 既報 ${ }^{(5)(6)}$ で使用された複合型プローブと同等の計測精度で流体中の速 度三成分と圧力の同時計測を行えることが明らかとなった。

3.2.2 乱れエネルギ収支

二次元乱流噴流の乱れエネルギ方程式は次式で表される .

$$
\underbrace{U \frac{\partial k}{\partial x_{1}}}_{\text {(A) }}+\underbrace{V \frac{\partial k}{\partial x_{2}}}_{\text {(B) }}+\underbrace{\overline{u v} \frac{\partial U}{\partial x_{2}}}_{\text {(C) }}+\underbrace{\left(\overline{u^{2}}-\overline{v^{2}}\right) \frac{\partial U}{\partial x_{1}}}_{\text {(D) }}+\underbrace{\hat{\varepsilon}}_{\text {(E) }}+\underbrace{\frac{\partial}{\partial x_{2}}\left(\frac{1}{2} \overline{v q^{2}}+\frac{1}{\rho} \overline{v p}\right)}_{\text {(F) }}=0
$$

ここで, $k$ と $\hat{\varepsilon}$ は

$$
\begin{gathered}
k \equiv \frac{\overline{q^{2}}}{2}=\frac{1}{2} \overline{\boldsymbol{u} \cdot \boldsymbol{u}}=\frac{1}{2}\left(\overline{u^{2}}+\overline{v^{2}}+\overline{w^{2}}\right) \\
\hat{\varepsilon}=v \overline{\left(\frac{\partial u_{i}}{\partial x_{j}}\right)^{2}}=\frac{1}{2}\left(\varepsilon_{i}+\varepsilon_{j}+\varepsilon_{k}\right) \\
\varepsilon_{i}=2 v\left\{\overline{\left(\frac{\partial u_{i}}{\partial x_{1}}\right)^{2}}+\overline{\left(\frac{\partial u_{i}}{\partial x_{2}}\right)^{2}}+\overline{\left(\frac{\partial u_{i}}{\partial x_{3}}\right)^{2}}\right\}
\end{gathered}
$$

で, $\varepsilon_{i}$ の添え字 $i=1,2,3$ は $u, v, w$ に対応する. Bradbury ${ }^{(20)}$ や寺島ら ${ }^{(4)(5)}$, 酒井ら ${ }^{(6)}$ の研究でこの乱れエネルギ 方程式の各項のエネルギの大きさ, すなわち乱れエネルギ方程式のエネルギの収支か評価されてきたが, いずれ 

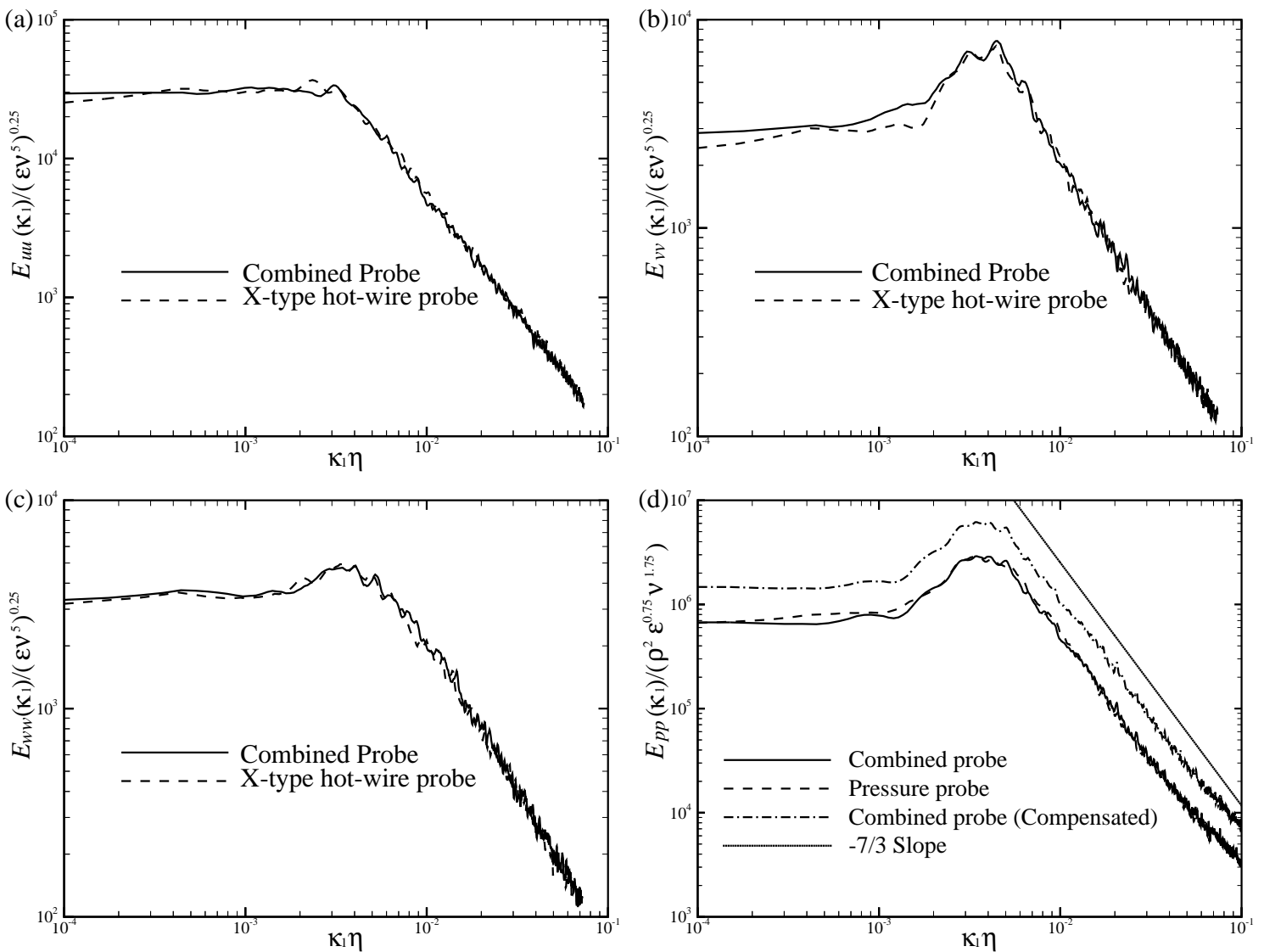

Fig. 11 Power spectra of (a) streamwise velocity fluctuation $E_{u u}\left(\kappa_{1}\right) /\left(\varepsilon v^{5}\right)^{0.25}$, (b) cross-streamwise velocity fluctuation $E_{v v}\left(\kappa_{1}\right) /\left(\varepsilon v^{5}\right)^{0.25}$, (c) spanwise velocity fluctuation $E_{w w}\left(\kappa_{1}\right) /\left(\varepsilon v^{5}\right)^{0.25}$ and (d) pressure fluctuation $E_{p p}\left(\kappa_{1}\right) /\left(\rho^{2} \varepsilon^{0.75} v^{1.75}\right)$. The measurements are performed at $x_{1} / d=20$ and $x_{2} / b=1.0$.

も速度三成分と圧力を同時に計測しておらず, 何らかの近似を行い, 各項の值を評価していた .一方, 本研究で製 作した複合型プローブは速度三成分と変動圧力を同時に計測できるため, 式 (8) に示した乱れエネルギ方程式の散 逸項 (式 (8) 中の (E) 項) 以外の全ての項を近似を行うことなく計測結果から直接評価することが可能となった . 光 こで本項では複合型プローブで計測した結果を用いて乱れエネルギ収支を評価し，従来の研究結果と比較して考 察した .

图 12(a) に $x_{1} / d=40$ における対流項 (式 (8) 中の (A) 項と (B) 項の和) , 生成項 (式 (8) 中の (C) 項と (D) 項の和)， 拡散項 (式 (8) 中の (F) 項) の噴流垂直 $\left(x_{2}\right)$ 方向分布を谷れ光れ示す. 横軸は噴流中心からの垂直方向距離 $x_{2}$ を噴 流の半値幅 $b$ で無次元化した值，縦軸は光れ帒れの項の值を噴流中心における主流方向平均速度 $\overline{U_{\mathrm{c}}}$ と噴流の半値 幅 $b$ を用いて ${\overline{U_{\mathrm{c}}}}^{3} / b$ で無次元化した值である. 図中の記号は, 四角が対流項, 三角が生成項, 下向きの三角か拡散 項，右向きの三角が散逸項の分布を表している．また，図中の実線，破線，一点鎖線，点線は光れ光れ既報 ${ }^{(5)(6)}$ で 求めた対流項，生成項，拡散項，散逸項の分布を表している.

図 12(a)より，本研究で得られた生成項の分布は Terashima ら ${ }^{(5)}$ の結果に比べ酒井ら ${ }^{(6)}$ の結果に近いものとなつ ている . Terashima ら ${ }^{(5)}$ の複合型プローブのX 型プローブを構成する二本の熱線の間隔が $1.5 \mathrm{~mm}$, 本研究および 酒井ら ${ }^{(6)}$ ののが $0.9 \mathrm{~mm}$ であったことを踏まえると, この生成項の分布の差異は X 型プローブの二本の熱線の距 離の差によるものと考えられる . また , 拡散項については, 拡散項の噴流垂直 $\left(x_{2}\right)$ 方向への積分值は理論的に 0 となるが, 本実験の結果では 0.013 となった .この值は著者らの過去の研究の結果 $\left(\right.$ Terashima ${ }^{(5)}$, 酒井ら ${ }^{(6)}$, 光

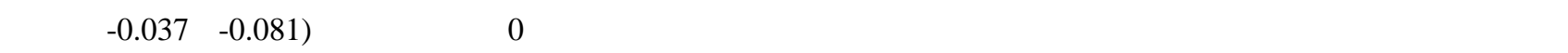
価精度の向上を果たしていると考えられる . なお，本研究で無次元化に用いた $\overline{U_{\mathrm{c}}}, b$ 既報 ${ }^{(5)(6)}$ で用いた值との差

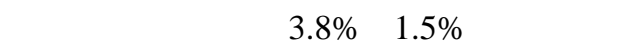

図 12(b) に $x_{1} / d=40$ における乱流拡散項 (式 (8) 中の (F) 項の第 1 項) と圧力拡散項 (式 (8) 中の (F) 項の第 2 項) 

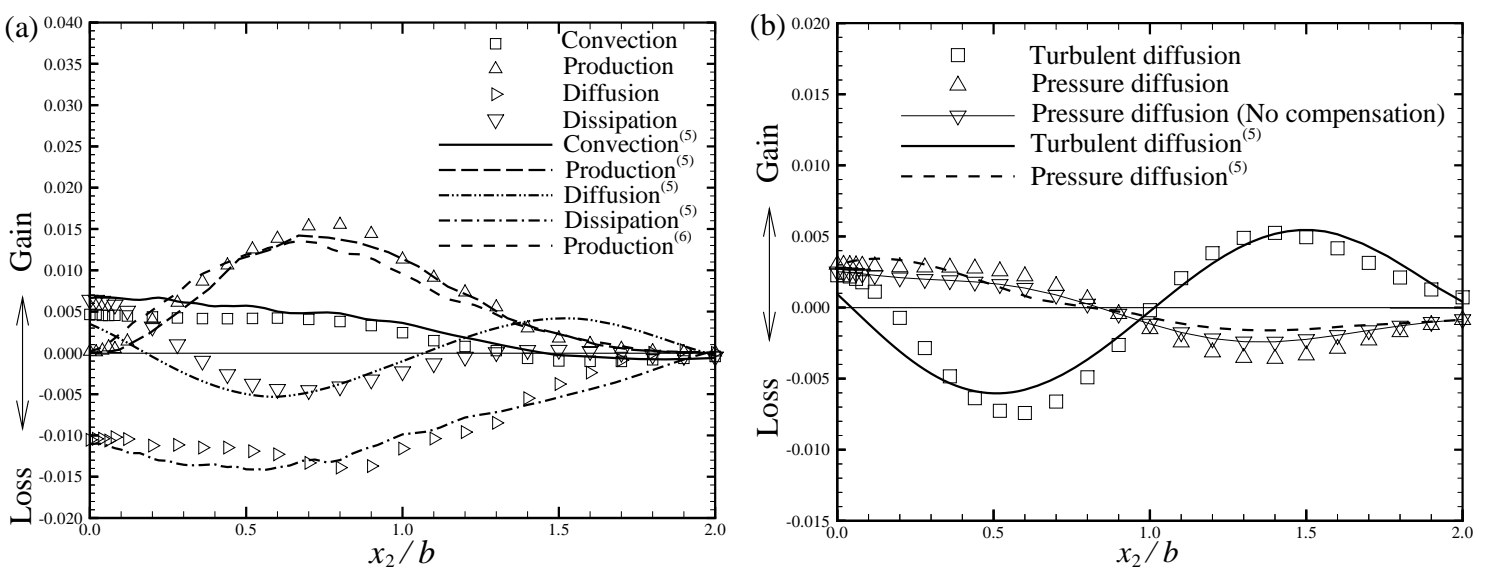

Fig. 12 Profiles of (a) convection, production, diffusion, and dissipation term, and (b) turbulent diffusion and pressure diffusion in the turbulent energy equation. The measurements are performed at $x_{1} / d=40$.

の噴流垂直 $\left(x_{2}\right)$ 方向分布を弚れ光れ示す. 横軸は噴流中心からの垂直方向距離 $x_{2}$ を噴流の半值幅 $b$ で無次元化し

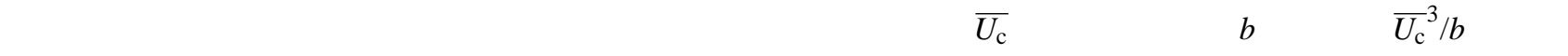
元化した值である . 図中の記号は, 四角が乱流拡散項 , 三角が圧力拡散項の分布を表している .また , 図中の実 線，破線は光れ光れ Terashima ら ${ }^{(5)}$ が求めた乱流拡散項，圧力拡散項の值を光れ表している. 图 12(b) より， 本実験で得られた乱流拡散項，圧力拡散項の分布ともにTerashima ら ${ }^{(5)}$ の結果と差異があることが分かる. これよ り, 図 12(a) で確認された拡散項の評価精度の向上は, 乱流拡散項と圧力拡散項の両方の評価結果の差異によるも のであることが明らかとなった .この乱流拡散項の評価結果の差異は, 速度三成分同時計測による $q^{2}$ の計測精度 向上，ならびに複合型プローブの検査体積の低減による速度と乱れエネルギの相関 $\left(\overline{v q^{2}}\right)$ の計測精度の差異による ものと考えられる . また , 圧力拡散項の評価結果の差異は, 静圧管の小型化による複合型プローブの検査体積の 低減や速度三成分の測定結果を基に変動圧力計測結果の補償を行ったためであると考えられる．

\subsection{3 圧力拡散による乱れエネルギ輸送に関する考察}

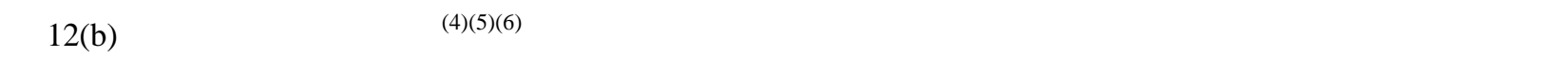
ていることが明らかにされている，乥こで, 最後にこの圧力拡散による乱れエネルギの輸送について, 計測した 変動速度と変動圧力の光れ光れにバンドパスフィルタ処理を施し, 圧力拡散項を各周波数成分ごとに評価, 比較 して考察する。

図 13 に圧力拡散項を各周波数成分ごとに評価した結果を示す. 図 13 の横軸と縦軸は図 12(b) と同一である. 図 13 の実線はバンドパスフィルタ処理を施さない, すなわち図 12(b) に示した圧力拡散項の分布 , 黑色の四角は 0-20 Hz , 黑色の三角は 20-40 Hz , 下向きの三角は 40-60 Hz , 白色の四角は 60-80 Hz , 白色の三角は 80-100 Hzの 変動成分により算出した圧力拡散項の分布を表している . 図 13 より，噴流外縁から中心への圧力輸送は主に 20-40 $\mathrm{Hz}$ の変動成分により生じていることが分かる．20-40 Hz の周波数帯域は，この実験条件下における二次元噴流に て発生するフラッピング現象の周波数である $25 \mathrm{~Hz}^{(21)}$ を含む帯域であることから，二次元噴流における乱れエネ ルギの圧力輸送はフラッピンク現象と密接に関わっているものと考えられる .

\section{4. 結言}

本研究では, 速度三成分と変動圧力を同時に計測するためのプローブを製作し，二次元噴流を対象に光の計測 精度の評価を行った . 以下に得られた知見をまとめる .

1. 製作した複合型プローブで二次元乱流噴流中の速度三成分と変動圧力の同時計測を行い, 誤差要因から考案 した補正・補償を行った結果, 本研究で製作した複合型プローブは静圧管の小型化により検査体積の低減が 図られた上, 計測対象とした $5,000 \mathrm{~Hz}$ 以下の変動周波数範囲において, 既報 ${ }^{(5)(6)}$ で使用された複合型プロー ブと同等の計測精度で流体中の速度三成分と圧力の同時計測を行うことができた． 


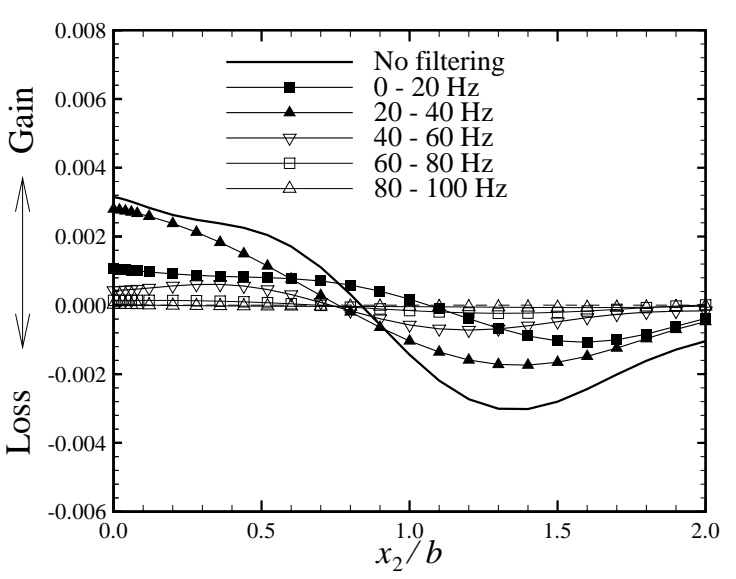

Fig. 13 Profiles of pressure diffusion in the turbulent energy equation. The measurements are performed at $x_{1} / d=40$.

2. 複合型プローブによる速度三成分と変動圧力の同時計測結果を用いて二次元乱流噴流の乱れエネルギ収支を 評価した結果, 従来の研究と比較して拡散項の噴流垂直方向への積分值がより0に近い值 $(-0.037 \rightarrow 0.013)$ と なり, 評価精度が向上した .

3. 2 の拡散項の分布を乱流拡散項の分布と圧力拡散項の分布に分けて考察した結果 , いずれの分布にも従来の結 果との差異が確認された .これより，この拡散項の評価精度の向上は, 速度-乱れエネルギ相関 $\left(\overline{v q^{2}}\right)$ と速度圧力相関 $(\overline{v p})$ の評価結果の差異によりもたらされたものと考えられる .

4. 圧力拡散項の分布を各周波数成分に分けて評価した結果 , 本実験の条件下におけるフラッピンク現象の周波 数 $(25 \mathrm{~Hz})$ を含む帯域の変動成分による圧力拡散が最大となった .これより，二次元噴流中の乱れエネルギの 圧力拡散はフラッピンク現象と密接に関わっている可能性が示された .

謝辞

本研究を遂行するにあたり，公益信託 小野音響学研究助成基金，科学研究費補助金 (23760155)，一般社団法人 カワイサウンド技術・音楽振興財団，株式会社日立製作所による財政的な支援を受けた．また，実験の遂行に際 しては名古屋大学の庄司裕一氏に協力を得た .ここに記して関係各位に謝意を表す．

文献

(1) Naka, Y., Omori, T., Obi, S., Masuda, S.," Simultaneous measurements of fluctuating velocity and pressure in a turbulent mixing layer " , International Journal of Heat and Fluid Flow, Vol. 27 (2006), pp.737-746.

(2) Liu, X., Katz, J.,' Instantaneous pressure and material acceleration measurement using a four-exposure PIV system”, Experiments in Fluids, Vol. 41 (2006), pp.227-240.

(3) Tsuji, Y., Fransson, J.H.M., Alfredsson, P.H., Johansson, A.V.," Pressure statistics and their scaling in highReynolds-number turbulent boundary layers ", Journal of Fluid Mechanics, Vol. 585 (2007), pp.1-40.

(4) 寺島修, 酒井康彦, 庄司裕一, 小島悠揮, 長田孝二, 久保貴 “; 二成分瞬間速度と瞬間圧力同時計測用複合型 プローブの改良と二次元乱流噴流の乱れエネルギ輸送評価に関する研究”，日本機械学会論文集 B 編，Vol.76， No.771 (2010) , pp.1831-1840.

(5) Terashima, O., Sakai, Y., Nagata, K., " Simultaneous measurement of velocity and pressure in a plane jet", Experiments in Fluids, Vol. 53, No. 4 (2012), pp. 1149-1164.

(6) 酒井康彦, 長田孝二，森口優 , 久保貴 “; 二成分瞬間速度と瞬間圧力の同時測定による二次元乱流噴流の構造 に関する研究 (速度変動と圧力変動の相互相関係数およびエネルギ収支の実験的評価) ”, 日本機械学会論文 集 B 編，Vol.75，No.758 (2009)，pp.2029-2035． 
(7) Pope, S.B., Turbulent Flows (2000), Chapter 7, pp. 264-332 and Chapter 11, pp. 387-462, CAMBRIDGE UNIVERSITY PRESS.

(8) Geipel, P., Henry Goh, K.H., Peter Lindstedt, R.,“ Fractal-Generated Turbulence in Opposed Jet Flows ” , Flow Turbulence Combust, Vol. 85, Issue 3-4 (2010), pp. 397-419.

(9) 新美智秀 “, 高クヌッセン数流れの光計測” , 日本機械学会論文集 C 編 , Vol.76 , No.768 (2010) , pp.1893-1895 .

(10) Fuchs, H. V.," MEASUREMENT OF PRESSURE FLUCTUATIONS WITHIN SUBSONIC TURBULENT JETS”, Journal of Fluid Sound and Vibration, Vol. 22, No. 3 (1972), pp.361-378.

(11) Toyoda, K., Okamoto, T., Shirahama, Y., Education of Vortical Structures by Pressure Measurements in Noncircular Jets ” , Applied Scientific Research, Vol. 53 (1994), pp.237-248.

(12) Goldschmidt, V. W., Young, M. F., Ott, E. S., “ Turbulent convective veloxcities (broadband and wavenumber dependent " , Journal of Fluid Mechanics, Vol.105 (1981), pp.327-345.

(13) Sakai, Y., Moriguchi, Y., Tanaka, N., Yamamoto, M., Kubo, T., Nagata, K.," On Characteristics of Velocity and Pressure Field in Two-Dimensional Turbulent Jet " , Journal of Fluid Science and Technology, Vol. 2, No. 3 (2007), pp.611-622.

(14) 庄司裕一, 寺島修, 酒井康彦, 長田孝二 “; 計測精度の向上を目的とした速度・圧力同時計測用プローブの改 良”，日本実験力学会論文集，Vol.11，No.3 (2011)，pp.229-234．

(15) Sakai, Y., Tanaka, N., Kushida, T., On the Development of Coherent Structure in a Plane Jet (Part1, Characteristics of Two-Point Velocity Correlation and Analysis of Eigenmodes by the KL Expansion) " , JSME International Journal, Series B, Vol.49, No.1 (2006), pp.115-124.

(16) Sakai, Y., Tanaka, N., Kushida, T.," On the Development of Coherent Structure in a Plane Jet (Part2, Investigation of Spatio-Temporal Velocity Structure by the KL Expansion) ” , JSME International Journal, Series B, Vol.49, No.3 (2006), pp.714-721.

(17) 西岡通男, 佐藤浩 “低杂隹音, 定温度型熱線風速計の試作”, 東京大学宇宙航空研究所報告, 第 6 巻 3 号 A (1970), pp. 571-589.

(18) Batchelor, G.K.," Pressure fluctuation in isotropic turbulence " , Proceedings of Cambridge Philosophical Society, Vol. 47 (1951), pp. 359-374.

(19) Tsuji, Y., Ishihara, T.," Similarity scaling of pressure fluctuation in turbulence” , Physical Review E, Vol. 68, 026309 (2003), 5 Pages.

(20) Bradbury, L.J.S.," The structure of a self-preserving turbulent plane jet” , Journal of Fluid Mechanics, Vol.23, part1 (1965), pp.31-64.

(21) 寺島修, 酒井康彦，長田孝二“; Flapping 現象発生時の二次元乱流噴流の諸特性”，日本機械学会論文集 B 編， Vol. 78 , No. 787 (2012), pp. 553-565. 